\title{
EFFICACY OF STUDYING AS PREDICTOR OF HIGHER EDUCATION QUALITY: THE CASE STUDY OF FACULTY OF AGRICULTURE
}

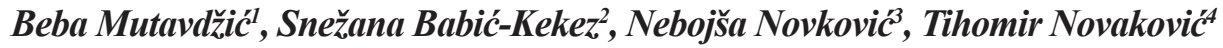

\begin{abstract}
Summary
Creation of education policy starts at, among other things, the vision of education system's quality. Comprehension of the concept of quality is multifaceted, so in higher education the holistic, multidisciplinary approach is the most appropriate for it acknowledges different segments of quality. One of those is measuring efficiency of studying based on input: type of high school, and the success achieved in high school, what is the goal of this research. Applying regression analysis on a sample of 1,114 subjects, students of the Faculty of Agriculture, the influence of success in high school to the average years of study and accomplished success during studies had been explored. For all courses, defining the influence of success in high school to the average years of study had negative coefficient of correlation, which means that by increasing the number of points earned in high school there is a decrease of average years of study (sum coefficient, $r=-0.23$ ). Due to the fact that the problem is in the uneven criteria of evaluation and assessment at high school level of education in Serbia, especially between high schools and vocational schools, results of this research are pointing out the necessity for equalization and compatibility of all elements in education system, and of bringing national outcomes of education at all levels and national qualification frames.
\end{abstract}

Key words: quality of higher education, studying efficacy, educational policy.

JEL: C20, I210, I240, Q19

1 Beba Mutavdžic, Ph.D., Assistant Professor, University of Novi Sad, Faculty of Agriculture, Dositeja Obradovića square no. 8, 21000 Novi Sad, Serbia, Phone: + 38162200 133, E-mail: bebam@polj.uns.ac.rs

2 Snežana Babić-Kekez, Ph.D., Assistant Professor, University of Novi Sad, Faculty of sciences, Dositeja Obradovića square no. 3, 21000 Novi Sad, Serbia, Phone: + 3812148527 61, E-mail: snezanabk@gmail.com

3 Nebojša Novković, Ph.D., Professor, University of Novi Sad, Faculty of Agriculture, Dositeja Obradovića square no. 8, 21000 Novi Sad, Serbia, Phone: + 38162200 133, E-mail: nesann@polj.uns.ac.rs

4 Tihomir Novaković, B.Sc., Teaching Fellow, University of Novi Sad, Faculty of Agriculture, Dositeja Obradovića square no. 8, 21000 Novi Sad, Serbia, Phone: + 3816461495 26, E-mail: tihomr_novakovic@hotmail.com

EP 2016 (63) 3 (997-1014) 


\section{Introduction}

Traditional role of education in the acquisition of knowledge of an individual and development of his abilities is getting new features by conditioning the readiness of the entire education system for fast transformation and adjustment to those demands and changes (Šegrt, Kolarski, 2015). In these processes, the role of university is aimed to promoting knowledge and skills needed in $21^{\text {st }}$ century, transfer of knowledge and overall strengthening of its bonds with society, their better interaction and fulfilment of common goals, and also achieving social and individual educational needs (Babić-Kekez, 2009). In developing their curricula, much will depend on the determination of higher education institutions to confront some cherished traditions in teaching and learning (Yorke, 2003). That is of exceptional importance for creating education policy and reform processes in education system especially in countries in social transition, like Serbia.

Whilst creating education policy it is very important to define minimum requirements for ensuring education quality. Thereby, it is necessary to determine the meaning of quality, knowing that there are different approaches and understanding of education quality. Whether the word 'quality' is used or not, every education system is structured around a certain vision of education quality. Within that frame, it is possible to talk about at least five alternative concepts of education quality: 1. Education quality as excellence. Where excellence is the vision leading the education process. 2. Education quality as consistency. Here equality represents the vision guiding the educational efforts. 3. Education quality as fitting the purpose. Precision and perfection in some subject areas represent the vision forming the education system. In this context, education quality is seen as preparation (specialization) of students for certain roles. 4. Education quality as 'value for money'. This means that quality of education corresponds with personal and social investments. 5. Education quality as transformative potential. In this context, social and personal changes represent the vision guiding educational efforts. Quality in education represents basis for positive changes of an individual and the society (Harvey, 2009). Said concepts can be implemented in education policy nonexclusively, on the contrary, they can double the demands and ensure higher level of quality.

Operationalizing of demands for quality in higher education is not new: there have been offered number of disputes and definitions of quality. Holistic, multidisciplinary approach in defining the quality in higher education is the most appropriate, the approach that takes care of interests of all in education and considers its different segments (Kovač, et all., 2002). One of those segments is evaluation, internal and external measurement of system efficiency. Quality is often set as effectiveness, the level of desired objectives achieved. In that case, high quality means increase of effectiveness that is locally defined. On one hand, quality can be set as incamation of characteristics (meaning excellence) that is accepted by certain society. On the other hand, quality can transfer to ability to come to results, as in the term 'school quality' (Milutinović, 2009; Easton, 2005). This paper considers quality of education from evaluation segment, measuring efficiency of the system, respectively we have researched the efficiency of studying as one of the predictors of education quality. 
In legal and strategic documents referring to higher education system in Serbia, quality of education is provided by demands for higher quality of environment/conditions of the program/curriculum process of class/learning and learning outcomes, applying the system of accreditation of institutions and programs of education, according to international standards and establishing international cooperation in monitoring and evaluation of quality of education system (Strategy of education development in Serbia, Official Newsletter, RS,72/2012.). Meaning that quality is normatively established by prescribed standards and that consensus is reached on national (local) level. Amongst theoretics prevails the attitude that standard is normative demand accordingly managing the education system, respectively, education standard can be directly bound to outcome value as outcome standards (outcome, achievement, efficiency), but can be regulational, editing the process (Pastuović, 2005). Considering that correctly fortified standards and criteria for enrolling at faculties (success in some four-year high school), we can talk about input standards. In this way, speaking, it is very simple to determine the efficiency of studying as a predictor of quality, expressed through coefficiency of input and output achieved standard (DEA-Data Envelopment Analysis). However, the problem lies in uneven criteria for evaluation and assessment at high school education level, especially between high schools and vocational schools, due to non-existing national education outcomes. Measuring the efficiency of studying and quality of teaching process itself, is more difficult because we have students with different input parameters, such as average grade in high school and number of points won in entrance exam and output parameters - average grade during studies as well as years of studying. This way we would, beside the measure of study efficiency, in a way measure the successfulness of high schools which students come from (Bojanić et all., 2015). In that sense, the results of this research are, among other things, function of pointing out the necessity for equalization and compatibility of all elements in education system, and of bringing national outcomes of education at all levels and national qualification frames.

Student success is a subject which has been analysed by many authors in different ways. However, all of them agree that the success of students at the undergraduate level is best determined by analysing the length of studies, and the average grades achieved during the studies as the best indicators of success. The average length of studies and the success achieved at the studies is affected by a number of factors, including the level of previously acquired knowledge, the conditions at the faculty, etc. The evaluation of faculty teaching by students has come to be one nearly ubiquitous measure of teaching effectiveness and, often, a major consideration for promotion, tenure and merit at most institutions of higher education (James et al., 2008). The aim of this research is to determine the effect of the secondary school previously attended by students, and their success achieved in the secondary school to the efficiency of studying. It is clear that previous education has a significant effect on the results achieved by students, but these relations need a more detailed analysis, which is the subject of this study.

In developing their curricula, much will depend on the determination of higher education institutions to confront some cherished traditions in teaching and learning. 


\section{Method}

The subject of the present research is the success and the average duration of studying of graduate students of Faculty of Agriculture in Novi Sad as a function of their secondary school success and the type of secondary school from which they are coming.

The aim of the research is determining the effect of success achieved in secondary school and the type of secondary school on the length of studies and the success achieved during the studies.

The relations between the observed variables were analysed using different statistical methods (Milojević, Zekić, 2015). Using descriptive analysis, the structure of graduate students was first graphically represented based on several indicators, such as the share of graduates by departments, their average grade, length of study, which was then followed by the analysis and determination of dependence of these results on the secondary school from which students came and the success they achieved in secondary school.

Similar methods were used for different problems (Janošević et. all, 2010; Kuiper, College, 2008; Vukelić, Novković, 2009; Vukelić et al., 2010; Aberson, 2014; Muller, Hofmann, 2014).

The relations that govern the dependent and independent variables were identified using regression analysis. The data were analysed using the Statistica 12, statistical analysis software package.

The observed data refer to the students graduated from the Faculty of Agriculture in Novi Sad in the period from 2000 to 2014. The collected database is incomplete, but it is sufficient for analysing and testing the significance between individual variables.

\section{The structure of graduate students by departments}

The data available refer to 1.114 students from seven different departments of the Faculty of Agriculture in Novi Sad (agroeconomy, veterinary medicine, phytomedicine, farming, animal husbandry, pomiculture and viticulture, and agricultural engineering), who graduated over the period between 2000 and 2014.

The data also refer to the type of secondary school from which students come, the number of credits which they bring from the secondary school, duration of studies, and the success achieved during the studies.

The structure of students graduated in the observed period by departments is presented in Chart 1. 
Chart 1. Structure of graduate students by departments for the period of 2000-2014

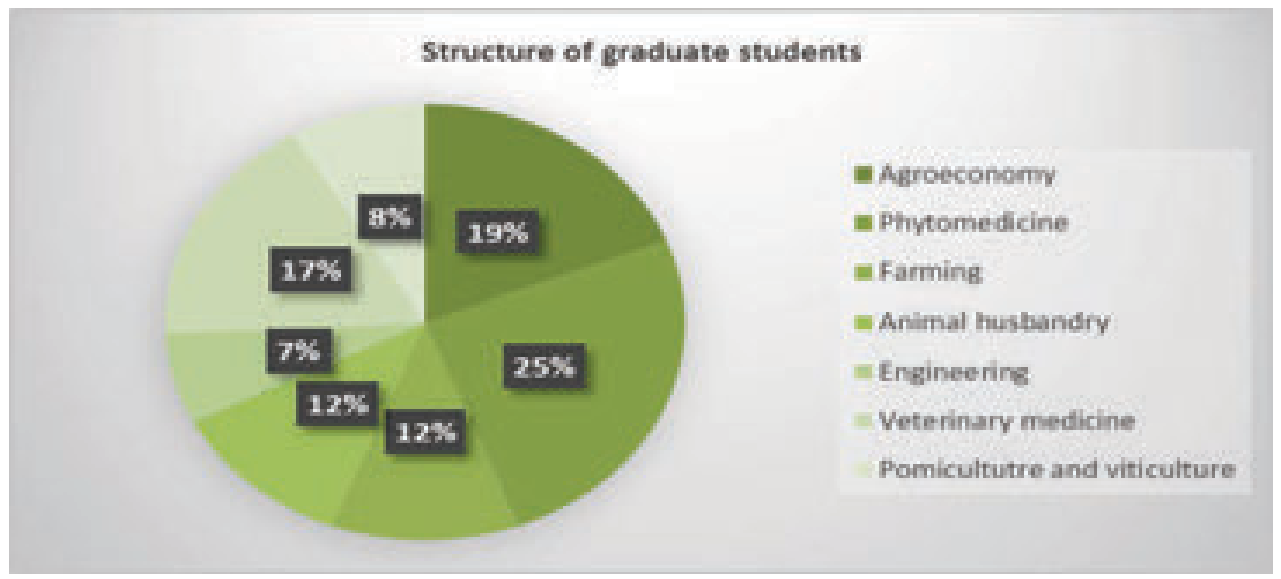

Source: Author's Analysis

As indicated by the above graphical presentation, most students in the observed period have graduated from the Department of Phytomedicine. They make a quarter of the total graduates in the reporting fourteen-year period.

Then follow the departments of agroeconomy (18.85\%), veterinary medicine $(17.15 \%)$, farming $(11.67 \%)$, animal husbandry $(11.58 \%)$, pomiculture and viticulture $(8.44 \%)$, and agricultural engineering $(6.73 \%)$.

The average years of studying and the average grade achieved by the students during their studies is presented in Chart 2.

The duration of studies ranged from 6.93 years (department of phytomedicine) to 8.04 years (department of farming).

Chart 2. Average number of years of studying and the average grades for the observed period by departments

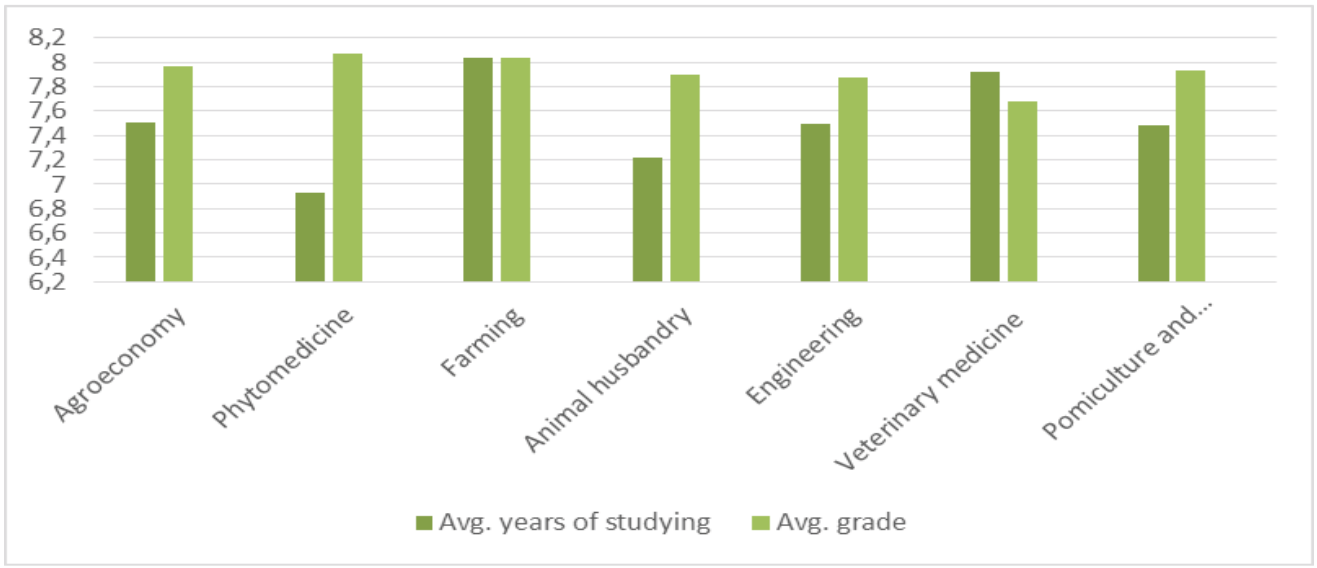

Source: Author's Analysis

EP 2016 (63) 3 (997-1014) 
An interesting fact is that students from the department of farming, although studying the longest, also have a rather high average grade compared to the students of other departments (8.04) which puts them on the second place behind students of phytomedicine whose average grade is 8.07 . They are followed by the students of agroeconomy (7.97), followed by the students of pomiculture and viticulture (7.93), animal husbandry (7.90), agricultural engineering (7.88) and veterinary medicine (7.68).

The number of credits brought by the students of different departments from secondary school is presented in Chart 3.

The highest number of credits from secondary school on average is brought by the graduates from the department of veterinary medicine (34.68), with students of pomiculture and viticulture being the weakest in this respect (31.10). Somewhat better were the students who graduated from the departments of agricultural engineering (31.25), animal husbandry (31.33), farming (32.64), while the students of agroeconomy (33.68) and phytomedicine (34.43) were scoring rather good.

Chart 3. Average number of credits brought by students from secondary school by departments

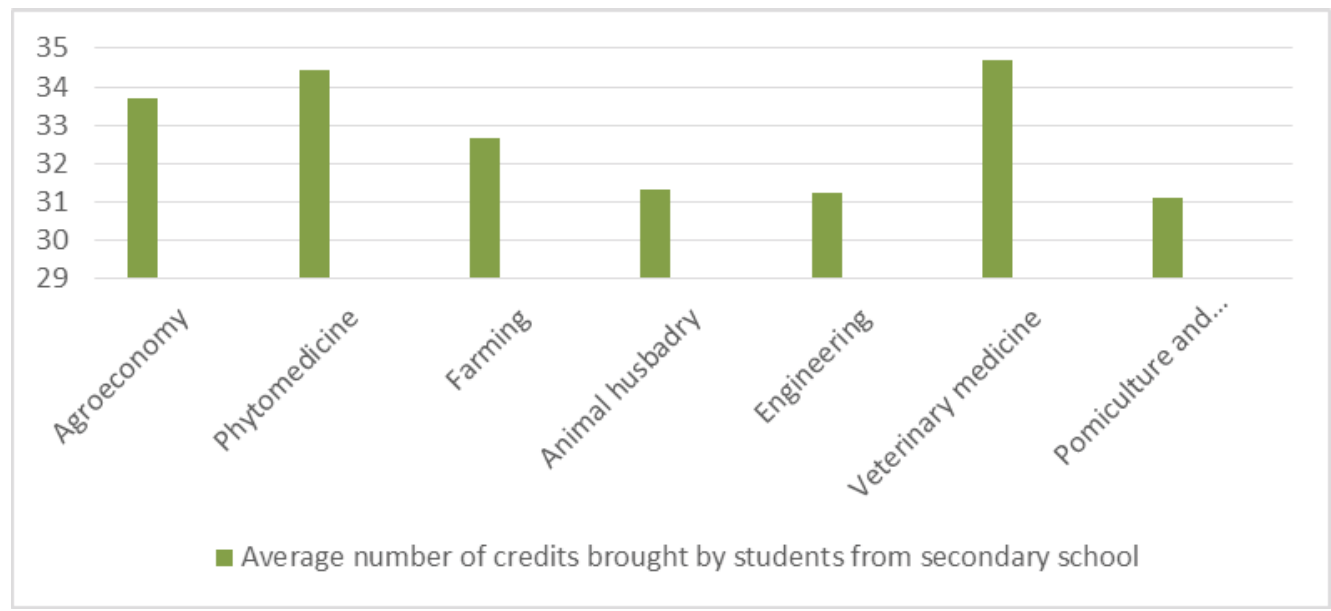

Source: Author's Analysis

\section{The structure of graduates based on the secondary school they attended}

When analysing the type of secondary school previously attended by the students who graduated in the reporting period, it can be seen that the most successful students come largely from grammar school (as many as $40.36 \%$ ). They were followed by the students coming from secondary school of agriculture (31.39\%), secondary technical school (12.91\%), secondary school of economy $(7.73 \%)$, while the lowest share is that of the students who attended secondary medical school (7.17\%), see Chart 4. 
Chart 4. Shares of secondary schools previously attended by the students who graduated in the reporting period $(\%)$

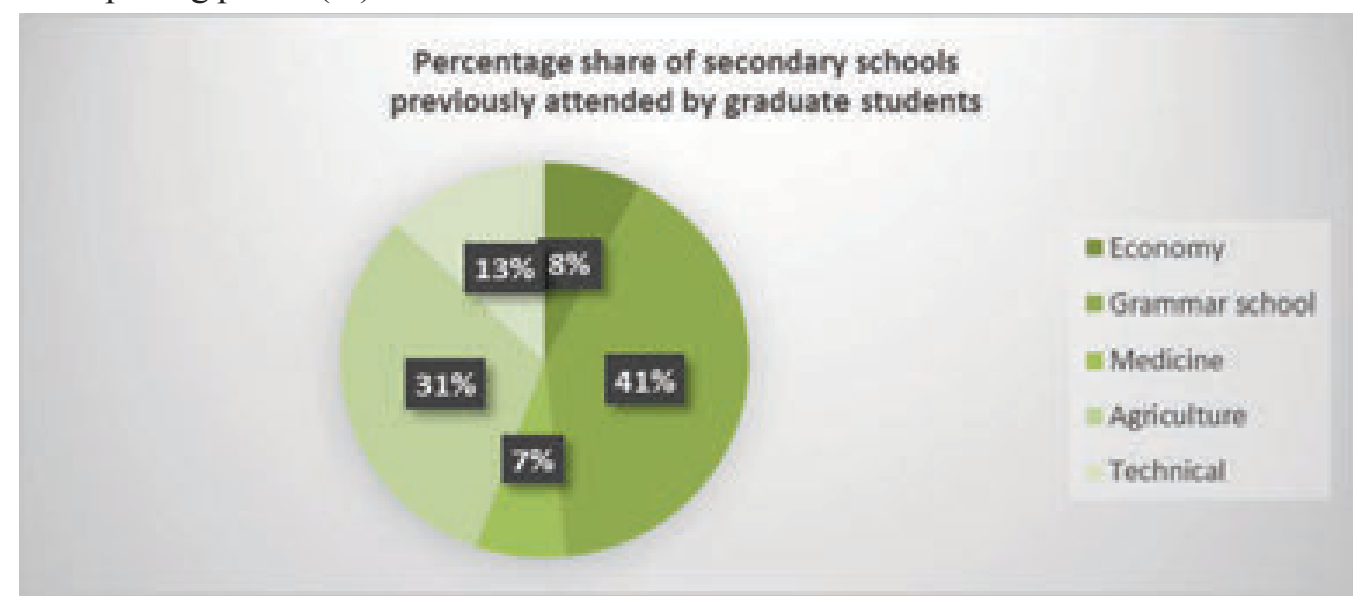

Source: Author's Analysis

The average number of credits brought by the students from these secondary schools is presented in Chart 5.

As indicated by the above data, the students with the highest number of credits (35.42) came from medical school. They were followed by the students from the school of economy (33.86), grammar school (33.44), agriculture (33.03) and secondary technical school (31.67). The average number of credits brought by the students from secondary school is 33.26 .

Chart 6 shows the students' average length of studies and the success they achieved as a function of secondary school they previously attended.

The shortest duration of studying was that of the students coming from secondary medical school - 7.06 years. Students coming from grammar school needed 7.33 years on average to finish their studies, while economists needed 7.59 years. Students coming from secondary technical schools finished their studies for 7.50 years on average, while the most time is need when the students previously attended secondary agricultural school - 7.64 years. The total average length of studies was 7.46 years. 
Chart 5. Average number of credits brought by the students from secondary school by the type of school

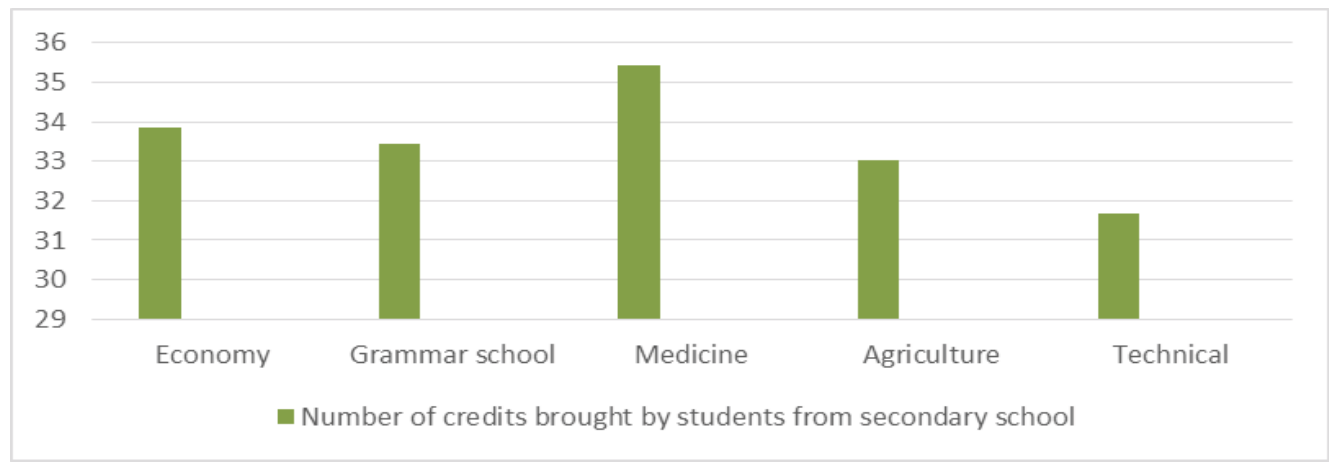

Source: Author's Analysis

The highest average grade during studies is achieved by students coming from grammar school.

They were followed by the students previously attending medical school 8.02, economy 7.98, technical school 7.83, while the list is closed by those coming from secondary agricultural school (7.71). The total average grade was 7.94 .

Chart 6. Average length of studies and average grades as a function of secondary school previously attended.

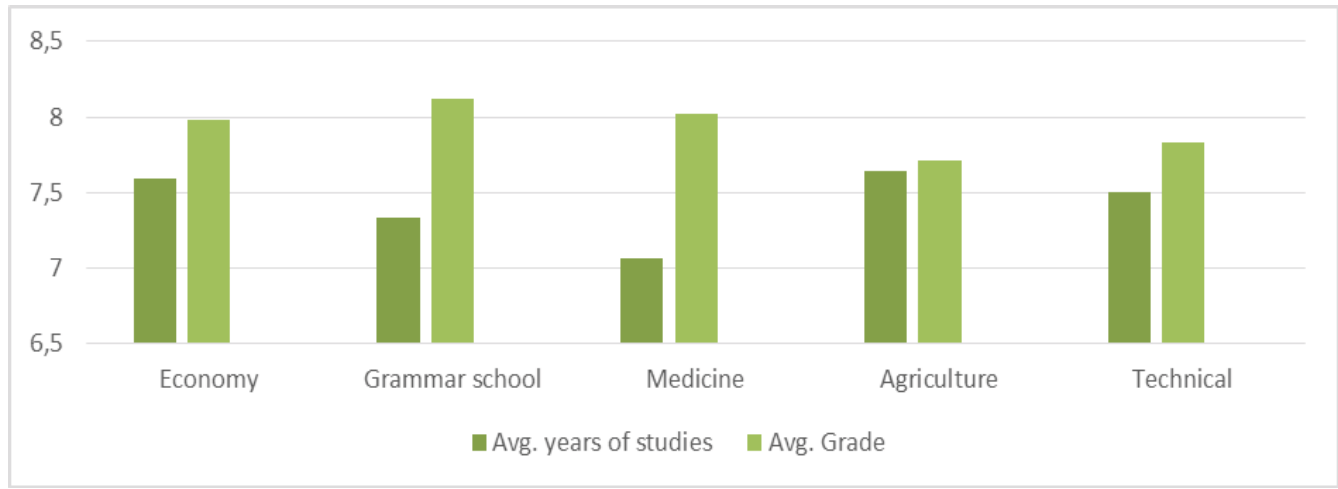

Source: Author's Analysis

\section{Shares of secondary of schools previously attended by departments from which students were graduated}

In the next step, the structure of secondary schools previously attended by students was analysed in relation to individual departments.

Agroeconomy is clearly dominated by the students coming from grammar school. The second place is held by the students coming from economic school. Together, these schools make $79 \%$ of graduates (Chart 7). 
Chart 7. Structure of secondary schools previously attended by graduates from the department of agroeconomy

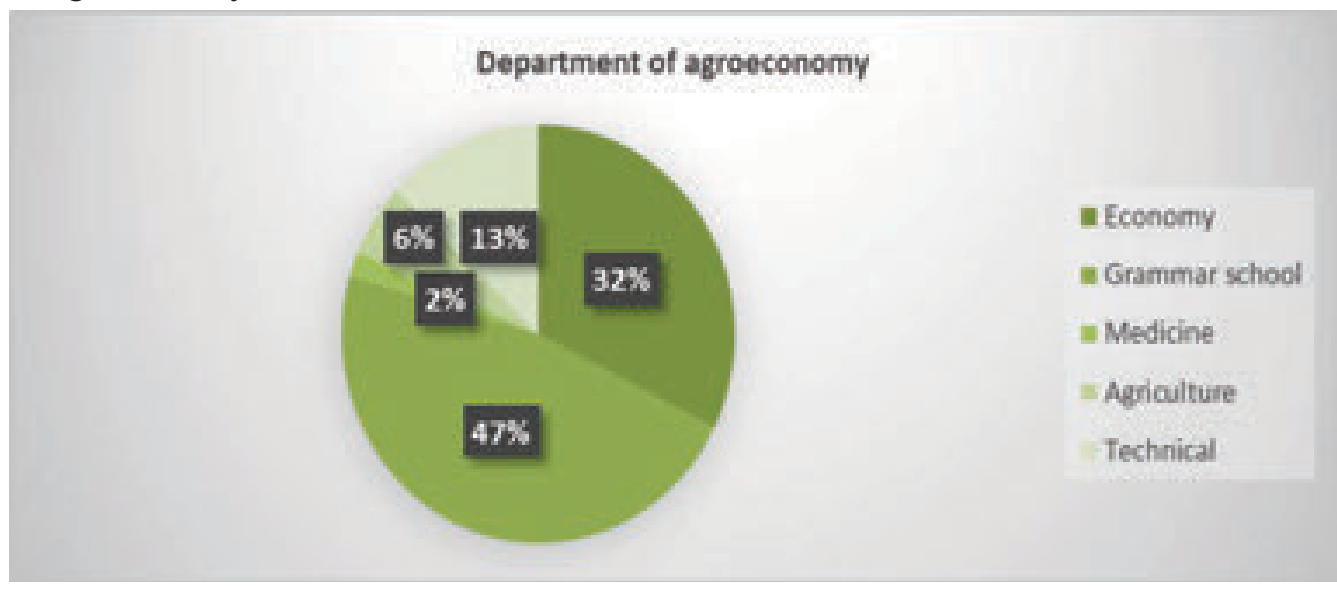

Source: Author's Analysis

The department of Phytomedicine is also dominated by the students coming from grammar school, making over half of the total number of the graduates $(51 \%)$. They are followed by the students coming from secondary agricultural (21\%), medical (16\%), technical $(10 \%)$ and economic school $(2 \%)$.

The graduates from the department of farming are mostly coming from grammar school (47\%). They are followed by the students coming from agricultural (27\%), technical (15\%), medical (7\%) schools, while those coming from secondary school of economy are at the end of the list (4\%), which is again expected.

The situation is somewhat different with the department of animal husbandry, which is significantly dominated by the students coming from secondary agricultural school with a share of $65 \%$ of total graduates. They are followed by those coming from grammar school $(22 \%)$, while the share of others is much lower: the share of the students previously attending secondary technical school is $9 \%$, while the students coming from medicine and economy jointly share the remaining $4 \%$ of the total graduates.

Most of the students from the department of agricultural engineering previously attended secondary technical school (61\%). They are followed by those coming from grammar school (22\%) and secondary agriculture (14\%), with the share of the students coming from secondary school of economy being the lowest (3\%). No students coming from secondary medical school have graduated from this department.

Interestingly, most of the students graduated in the reporting period from the department of veterinary medicine came from secondary school of agriculture - $60 \%$. The share of those previously attending grammar school is $31 \%$, while of those coming from medical school is only $8 \%$. It has been recorded that in the reporting period only one student who previously attended secondary school of economy has graduated from the department of veterinary 
medicine, which makes $0.52 \%$, while the students coming from secondary technical school were not represented.

At the department of pomiculture and viticulture, most graduates come from grammar school - 46\%. They are followed by the students previously attending secondary school of agriculture (35\%) and secondary technical school (14\%). The share of students coming from medical and economic school is rather small, $4 \%$ and $1 \%$, respectively.

\section{Results}

\section{The effects of the total number of credits brought by the students from secondary school on the length of studying}

In the next step, using regression analysis, the effect of secondary school success on the length of studies was analysed based on the number of credits (Table 1).

Table 1. Effect of the number of credits brought from secondary school on the length of studies

\begin{tabular}{|c|c|c|c|c|c|c|}
\hline \multirow[b]{2}{*}{$N=1114$} & \multicolumn{6}{|c|}{$\begin{array}{l}\text { Regession Summary for Dependent Variableyrs. of studies(List1 in input data } \\
R=22991593 \mathrm{R2}=05206134 \text { Adusted R2= } 05200959 \\
\mathrm{~F}(1,1112)=62,063 \text { p } 00000 \text { Std Errer of estimate: } 17316\end{array}$} \\
\hline & $b^{*}$ & $\begin{array}{c}\text { Std En } \\
\text { of } b^{*}\end{array}$ & $b$ & $\begin{array}{c}\text { Sid.En. } \\
\text { of } b\end{array}$ & $t(1112)$ & prabe \\
\hline Intercept & & & 10,55823 & 0,390074 & 26,59010 & 0,000000 \\
\hline Number of sec schoo oreds & 0.229916 & 0,029185 & 0.09325 & 0.011837 & +7.87798 & 0.00000 \\
\hline
\end{tabular}

Source: Result of prediction

As indicated by the results, as the number of credits that reflect the success in secondary school increases, the length of studies decreases. Increasing the number of secondary school credits by one shortens the duration of studies by about one month. This information is deduced based on the parameter $b$, or the regression coefficient.

Also, the correlation coefficient is observed to have a negative value (- 0.2299), which means that there is a negative correlation between the number of credits brought by students from secondary school and the number of years of studying. The squared correlation coefficient, or coefficient of determination (in this case 5.27\%), indicates that the dependence of the length of studies is explained with only about $5 \%$ of the number of credits brought by the students, while the remaining $95 \%$ is a result of unexplained factors (coefficient of nondetermination).

\section{The effects of the total number of credits brought by the students from secondary school on the average grade}

The number of credits brought by the students from secondary school is positively correlated with average grades during studies. Namely, increasing the number of credits for one, the average grade increases by about 0.06 (Table 2). 
Table 2. The effect of the number of credits brought from secondary school on the average grade during studies

\begin{tabular}{|c|c|c|c|c|c|c|}
\hline \multirow[b]{2}{*}{$N=1114$} & \multicolumn{6}{|c|}{$\begin{array}{l}\text { Regression Summary for Dependent Variable: average grade (Ustt in Input data } \\
R=39609917 \mathrm{R} 2=, 15904078 \text { Adjusted } R 2=, 15828452 \\
F(1,1112)=210,30,0.0000 \text { Std Enor of estimate. }, 80395\end{array}$} \\
\hline & $b^{*}$ & $\begin{array}{l}\text { Sid EIr. } \\
\text { of } b^{*}\end{array}$ & b & $\begin{array}{l}\text { Sid.Er. } \\
\text { of } b\end{array}$ & $t(1112)$ & pralose \\
\hline Intercept & & & 5,945775 & 0,138490 & 4295260 & 0,00 \\
\hline Bhriter of sec. achool eredes & 0396799 & 0.027500 & 0,059670 & 0.004128 & 1450171 & 0,00 \\
\hline
\end{tabular}

Source: Result of prediction

The 0.16 coefficient of determination indicates that $16 \%$ of the average grade during studies can be explained by the credits brought from secondary school.

\section{The effect of the secondary school success on the length of studies and the average grade by departments}

\section{Agroeconomy}

At the department of agroeconomy, increasing the number of secondary school credits for one makes the average duration of studies by 0.14 years shorter (Table3).

Table 3. The effect ofthe number ofsecondary school onthe length of studies

\begin{tabular}{|c|c|c|c|c|c|c|}
\hline \multirow[b]{2}{*}{$N=210$} & \multicolumn{6}{|c|}{$\begin{array}{l}\text { Regression Summary for Dependent Variable. yrs. of studies (List1 in agrol) } \\
R=32914515 R 2=, 10833719 \text { Adjusted } R 2=, 10405035 \\
F(1,208)=25,272 p<00000 \text { Std Enor of estimate: } 1,7155\end{array}$} \\
\hline & $b^{*}$ & $\begin{array}{l}\text { Std Ent. } \\
\text { of } b^{*}\end{array}$ & $b$ & $\begin{array}{c}\text { Sid.EII. } \\
\text { of b }\end{array}$ & $t(206)$ & p-value \\
\hline Intercept & & & 1227050 & 0954427 & 1285641 & 0,000000 \\
\hline Number of sec. school cresiss & .0329146 & 0,065474 & $-0,14136$ & 0.008120 & 5,02713 & 0,000001 \\
\hline
\end{tabular}

Source: Result of prediction

The coefficient of correlation has also a negative value, and it is statistically very important. The coefficient of determination is 0.10 , meaning that $10 \%$ of the length of studies can be explained by secondary school credits. The standard error of regression is 1.7155 . Table 4 shows the effect of credits on average student grades.

Table 4. The effect ofsecondary school creditson the average grade

\begin{tabular}{|c|c|c|c|c|c|c|}
\hline \multirow[b]{2}{*}{$N=210$} & \multicolumn{6}{|c|}{ 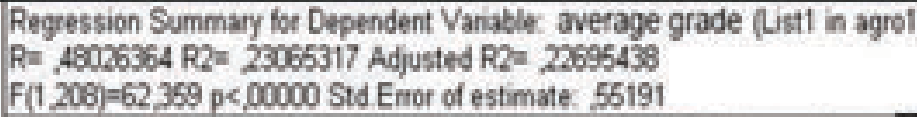 } \\
\hline & $b^{*}$ & $\begin{array}{l}\text { Sid.Ent. } \\
\text { of } b^{*}\end{array}$ & b & $\begin{array}{l}\text { Std Ent. } \\
\text { of } b\end{array}$ & $t(206)$ & prablet \\
\hline Intercept & & & 5,565408 & 0,307061 & 18,12479 & 0,000000 \\
\hline Number of sec. school credts & 0.400264 & 0,060818 & 0.071440 & 0.009047 & 789678 & 0,000000 \\
\hline
\end{tabular}

Source: Result of prediction

EP 2016 (63) 3 (997-1014) 
Here, there is a positive correlation between the average grade and the number of credits brought by the students - it is 0.4803 and it is statistically very significant. Increasing the secondary school credits by one, the average grade increases by 0.0714 . The number of credits participates in the average grade with $22.70 \%$. The average deviation of original values of the dependent variable of the estimated values is 0.552 .

Using scatter plots (Charts $\mathbf{8}$ and 9), the following part of this paper presents the regressions related to the analysis of the effect of students' secondary school credits on the length of studies and average grades.

Chart 8. Scatter plot for the years of studying against the credits brought by the students of agroeconomy from secondary school

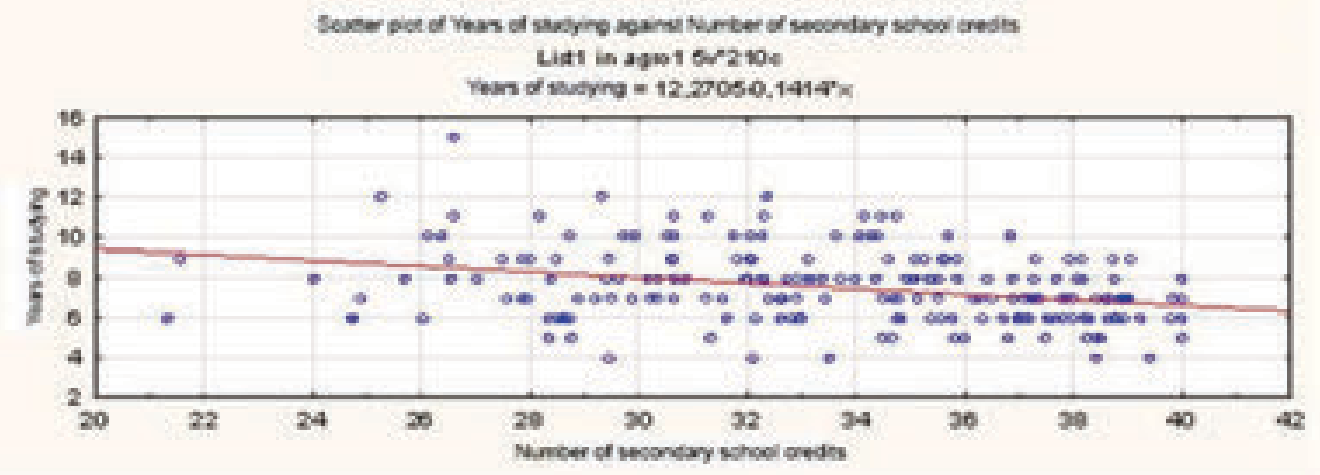

Source: Result of prediction

Chart 9. Scatter plot for the average grade against the credit brought by the students of agroeconomy from secondary school

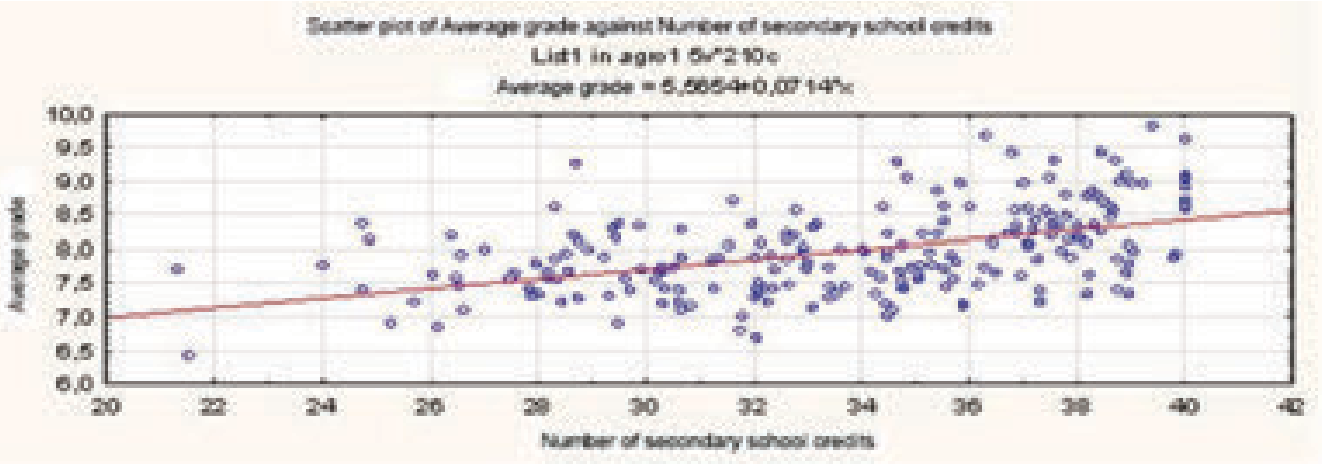

Source: Result of prediction

The above scatter plots confirm the observed relation between the secondary school success of the students of agroeconomy and the results of their study from the aspect of length of study and average grades achieved during the studies. 


\section{Phytomedicine}

For the department of Phytomedicine, the correlation coefficient between the credits and the length of study is -0.2697 , indicating a negative correlation between the two phenomena. Increasing credits for one, the average length of study shortens by 0.11 years.

Based on the coefficient of determination, it can be concluded that approximately $7 \%$ of the length of study is affected by the number of credits.

In the analysis of the effect of credits on the average grade of students there is a 0.5206 positive correlation between variable, which is statistically highly significant.

Increasing credits for one, the average grade among students of Phytomedicine is growing by about 0.086 . The dependent variable is explained with the independent variable in nearly $27 \%$.

\section{Farming}

There are certain changes when it comes to the students of farming in the observed effects compared to the students of agroeconomy and phytomedicine. Namely, the coefficient of correlation in this department is also negative, but the model based on which the effects of the success of these students in secondary school was considered on the length of studies was not statistically significant. This means that secondary education is not a decisive factor for the length of study of the students of the farming department.

At the department of farming, higher numbers of secondary school credits also imply shorter average studying. Increasing the number of credits by one, the average length of study is reduced by 0.061 years.

The small significance of credits for the length of study of students of farming is also indicated by the low coefficient of determination, which is as low as $1.74 \%$.

In contrast to the length of study where the secondary school success is not critical, their average grades of students of farming are significantly affected by their secondary school success. The coefficient of correlation is statistically highly significant -0.3457 - and indicates a positive linear relationship among the variables.

Increasing the number of credits for one, there is an increase in average grades of students of farming by approximately 0.05 .

Unlike the previous regression, here, the number of credits significantly affects the average grade $(11.27 \%)$, as indicated by the value of the coefficient of determination.

\section{Animal husbandry}

When it comes to the students of department of animal husbandry there is also a negative correlation between secondary school success and the length of studies, as indicated by the coefficient of correlation which is -0.3708 .

Increasing the number of secondary school credits for one, the duration of studies is reduced 
by approximately 0.16 years. The coefficient of determination is 0.13 , while the standard error of regression is 1.6661 .

On the other hand, the effect of credits on the average grade achieved during the studies is positive; expressed through the value of the coefficient of correlation, it is 0.3969 . On the average, increasing the number of credits for one, the average credit of students of this department increases for approximately 0.07 .

The coefficient of determination indicates a $15 \%$ effect of the number of credits on the average grade, while the effect of other factors is $85 \%$. These relations can be seen from the scatter plot (Chart 10).

Chart 10. Scatter plot of the average grade against the number of credits for the students of animal husbandry

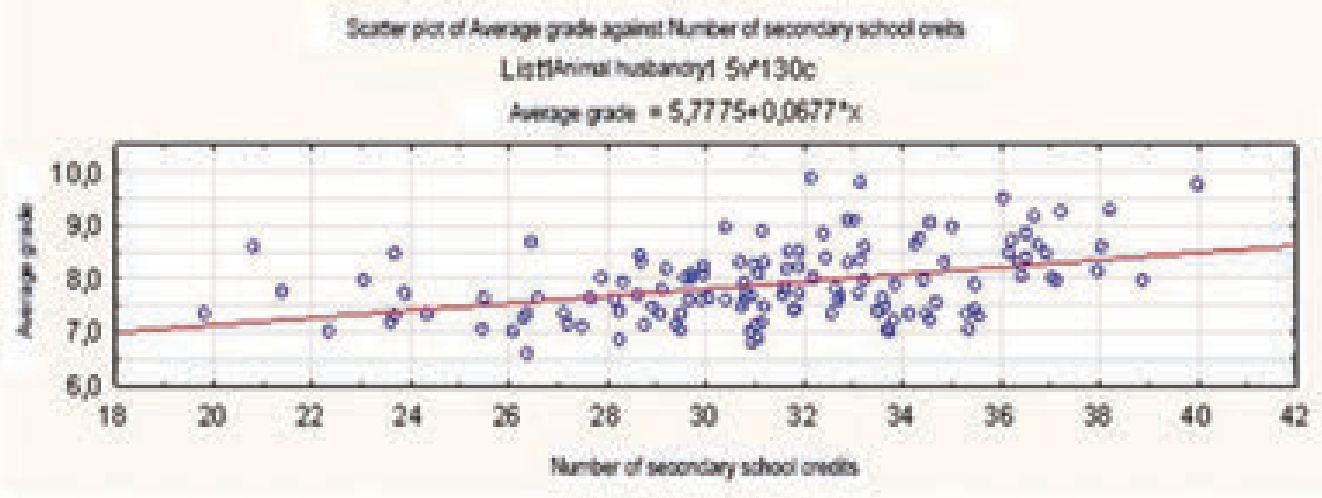

Source: Result of prediction

\section{Agricultural engineering}

As was the case with the previously observed departments, there is a statistically significant negative correlation between secondary school success and the length of study at the department of agricultural engineering as indicated by the coefficient of correlation $(-0.2497)$. The number of credits which reflects secondary school success affects the duration of studies in approximately 5\%. When increasing the number of credits for one, the length of studies decreases for 0.10 years.

Analysing the effect of secondary school success on success achieved during the studies reveals that increasing the number of credits for one leads to the increase in the average grade by 0.09 . The coefficient of correlation is positive and relatively high $(0.5461)$, indicating the importance of secondary education for the success of the students of agricultural engineering. The coefficient of determination is slightly higher and amounts almost 0.29 , which means that knowledge acquired in secondary school affects the average grade at the end of undergraduate studies with $29 \%$. 


\section{Veterinary medicine}

Similarly to the department of farming, a negative correlation has also been found between secondary school success and the length of studies at the department of veterinary medicine, which is not statistically significant, and it is -0.1338 . This suggests a minimum level of effect of secondary school credits on the average length of studies. At this department, increasing the number of credits by one reduces the average length of studies by only 0.06 years.

On the other hand, knowledge acquired in secondary school has a much higher effect on the average grade during the studies $(12.50 \%)$. Increasing number of credits for one, the average grade also increases by a little more than 0.05 .

\section{Pomiculture and viticulture}

Similar to the departments of veterinary medicine and farming, there is a negative correlation also at the department of pomiculture and viticulture, which is statistically not significant and indicates a minor effect of previously acquired knowledge on the length of studies. On the other hand, there is a statistically significant positive correlation between secondary school success and average grade at the end of studies, which is 0.3407 . The coefficient of determination indicates that secondary school credits affect the average grade during studies with nearly $11 \%$.

Increasing the number of credits by one, the average grade of the students at this department increases by approximately 0.05 .

\section{Conclusion}

The present research on the effect of the type of secondary school and the secondary school success on the length of studies and the success achieved during undergraduate studies of students of Faculty of Agriculture in Novi Sad provided some interesting results.

First, a descriptive analysis showed that the average age of studying is approximately 7 years and 6 months, with the average grade being 7.94. The average number of credits brought by students from secondary school is 33.26 .

There is the highest number of students graduated from the department of phytomedicine. The same department achieved the best average, which has not prevented the students from being the most effective in the terms of the duration of studies.

The students with the highest number of secondary school credits were those graduated from the department of veterinary medicine.

Regarding the secondary school they previously attended, the students coming from grammar school were the most successful. There is the highest percentage of graduate students coming from grammar school. The best average during studies has been achieved by the students previously attending grammar school. However, this made them somewhat slower, a fact which allowed students coming from secondary medical school to be the fastest to graduate. Students coming from secondary medical school also had the highest success during previous education.

EP 2016 (63) 3 (997-1014) 
In the terms of departments, students coming from grammar school accounted for the majority of graduates in agroeconomy, phytomedicine, farming, pomiculture and viticulture, while the majority of graduates of veterinary medicine and animal husbandry were previously attended secondary school of agriculture. Students coming of secondary technical schools are traditionally attracted by the department of agricultural engineering, so understandably the highest number of the students graduated from this department came from secondary technical school.

These data should be interpreted very carefully because the criteria used by different secondary schools in the process of evaluation are not quite uniform. Taking secondary school success as a relative indicator, and on the basis of its share among graduate students and the effect on the results achieved during the study, the conclusion is that the students previously attending grammar school are still more achieving than those come from other secondary schools.

In this paper, using regression analysis, the effect of secondary school success on the average length of studies and success achieved during the studies has been investigated. The analysis of the effect of secondary school success on average length of studies showed a negative coefficient of correlation in all departments, indicating that the increase of secondary school credits leads to the decrease in the average length of studies (total coefficient, $r=$ -0.23). In some departments, this indicator is statistically highly significant (agroeconomy, phytomedicine, animal husbandry, and agricultural engineering), while in the others it is insignificant (farming, veterinary medicine, pomiculture and viticulture), indicating that secondary school success has no statistically significant effect on the length of studies in these departments.

The effect of previously acquired knowledge on the success achieved during the studies is positively focused and thus determined by positive coefficient of correlation (overall coefficient $r=0.39$ ). Also, the success during the studies is much more effected by secondary school success (coefficient of determination, $\mathrm{r}^{2}=0.1583$ ) than the average length of studies (coefficient of determination, $\mathrm{r}^{2}=0.052$ ).

\section{References}

1. Aberson, C. L. (2014): Power analyses for detecting effects for multiple coefficients in regression, The Stata Journal, Texas A\&M University, USA,Vol. 14, No. 2, pp. 389-397

2. Babić-Kekez, S. (2009): The development of university teachers' competencies in order to insure the teaching quality, Ministry of Education and research, University Aurel Vlaicu, Arad, Romania, Educatia Plus, Anul VI.Nr.1. Vol. 9, pp. 97-107.

3. Bojanić, R., Kovačević, I., Nikolić, D., Konjović, Z. (2015): Efficiency of educational process as one of the ranking measures at universities, respectively, faculties, TREND 2015, University of Novi Sad

4. James, O., Douglas, A., Sanford, Jr., Douglas, N. R. (2008): Does ratemyprofessor.com really rate my professor? Assessment \& Evaluation in Higher Education, Routledge, Vol. 33, No. 4, pp. 355-368.

5. Janošević, M., Novković, N., Tešanović, D. (2010): Menadžment logističkog lanca u 
distribuciji hrane, Ekonomika poljoprivrede, No. 4, pp. 625-635, Belgrade

6. Kuiper, Sh., College, G. ( 2008): Introduction to Multiple Regression: How Much Is Your Car Worth?, Journal of Statistics Education, Vol. 16, No. 3, available at: (www. amstat.org/publications/jse/v16n3/datasets.kuiper.html)

7. Kovač, V., Ledić, J., Rafajac, B. (2002): Managing higher education institutions: Problems and solution approaches, Zagreb, Društvena istraživanja No. 6, pp. 1013-1030

8. Leu, E. (2005). The Role of Teachers, Schools, and Communities in Quality Education: A Review of the Literature, Washington, DC: Academy for Educational Development

9. Milojević, I., Zekić, M. (2015): Organizaciona struktura preduzeća kao pretpostavka konsolidacije bilansa, Oditor, Belgrade, Vol. 4, No. 3, pp. 22-28.

10. Milutinović, J. (2009): Different approaches to education quality, Zbornik Matice srpske za društvene nauke, Novi Sad, Vol. 128, No. 1, pp. 75-88.

11. Muller, C.M., Hofmann, V. (2014): Does being assigned to a low school track negatively affect psychological adjustment? A longitudinal study in the first year of secondary school, School Effectiveness and School Improvement, An International Journal of Research, Policy and Practice, Vol. 27, No. 2, pp. 95-115

12. Pastuović, N. (2005): Theory of curriculum, national, educational standard and catalogues of knowledge, Zagreb, Methodics, Vol. 6, No. 1.

13. SPSS Survival manual, Julie Pallant, 2007.

14. Hadživuković, S. (1989): Statistica, Privredni pregled, Beograd

15. Strategy of education development in Srbija, Official Newsletter, RS,72/2012

16. Schools and quality (1998): Beograd, Zavod za udžbenike i nastavna sredstva

17. Šegrt, S., Kolarski, I. (2015): Uslovi egzistencije preduzeća, Oditor, Belgrade, Vol. 4, No. 2, pp. 32-41.

18. Vukelić, N., Novković, N. (2009): Ekonomski rezultati proizvodnje mleka na krupnim seljačkim gazdinstvima, Ekonomika poljoprivrede No. 56, Belgrade pp. 99-110

19. Vukelić, N., Rodić, V., Novkovic, N., Bošnjak, D. (2010): An analysis of the Serbian poultry meat sector, Ekonomika poljoprivrede, Vol. 57, special no. 1, pp. 374-381, Belgrade.

20. Yorke, M. (2003): Formative assessment in higher education: Moves towards theory and the enhancement of pedagogic practice, Higher Education, Vol. 45, pp. 477-501. 


\title{
EFIKASNOST STUDIRANJA KAO PREDIKTOR KVALITETA OBRAZOVANJA: STUDIJA SLUČAJA POLJOPRIVREDNOG FAKULTETA
}

\author{
Beba Mutavdžič ${ }^{5}$, Snežana Babić-Kekez ${ }^{6}$, Nebojšă Novkovič $^{7}$, Tihomir Novakovič ${ }^{8}$
}

\begin{abstract}
Sažetak
Pri kreiranju obrazovne politike polazi se, između ostalog, od vizije kvaliteta obrazovnog sistema. Shvatanje pojma kvalitet je višeznačno, te je u visokom obrazovanju najprimereniji holistički, multidisciplinaran pristup koji uvažava različite segmente kvaliteta. Jedan od njih je merenje efikasnosti studiranja na osnovu ulaznih parametara: vrste srednje škole i postignutog uspeha u srednjoj školi. Primenom regresione analize, na uzorku od 1114 ispitanika, studenata Poljoprivrednog fakulteta, istraživan je uticaj uspeha u srednjoj školi na prosečan vek studiranja i ostvaren uspeh tokom studija. Kod svih smerova, prilikom definisanja uticaja uspeha u srednjoj školi na prosečan vek studiranja, koeficijent korelacije je negativan, što govori da sa povećanjem broja bodova iz srednje škole opada prosečan vek studiranja (ukupan koeficijent, $r=-0,23$ ). S obzirom na to da je problem u neujednačenim kriterijumima vrednovanja i ocenjivanja na nivou srednjoškolskog obrazovanja u Srbiji, posebno između gimnazija i srednjih stručnih škola, rezultati ovog istraživanja su, između ostalog, u funkciji ukazivanja na nephodnost ujednačavanja i kompatibilnosti svih elemenata sistema obrazovanja, donošenja nacionalnih ishoda obrazovanja na svim nivoima $i$ nacionalnog okvira kvalifikacija.
\end{abstract}

Ključne reči: kvalitet visoko školskog obrazovanja, efikasnost studiranja, obrazovna politika.

5 Docent, dr Beba Mutavdžic, Univerzitet u Novom Sadu, Poljoprivredni fakultet, Trg Dositeja Obradovića br. 8, 21000 Novi Sad, Srbija, Telefon: + 38162200 133,E-mail: bebam@polj.uns.ac.rs

6 Docent, dr Snežana Babić-Kekez, Univerzitet u Novom Sadu, Prirodno-matematički fakultet, Trg Dositeja Obradovića br. 3, 21000 Novi Sad, Srbija, Telefon: + 38121485 2761, E-mail: snezanabk@gmail.com

7 Redovni professor, dr Nebojša Novković, Univerzitet u Novom Sadu, Poljoprivredni fakultet, Trg Dositeja Obradovića br. 8, 21000 Novi Sad, Srbija, Telefon: + 38162200133 , E-mail: nesann@polj.uns.ac.rs

8 Saradnik u nastavi, dipl. men. Tihomir Novaković, Univerzitet u Novom Sadu, Poljoprivredni fakultet, Trg Dositeja Obradovića br. 8, 21000 Novi Sad, Srbija, Telefon: + 3816461495 26, E-mail: thomr novakovic@hotmail.com 